\title{
Seasonal diet of pine marten Martes martes in southern boreal Sweden
}

\author{
Jan Olof HELLDIN
}

\begin{abstract}
Helldin J. O. 2000. Seasonal diet of pine marten Martes martes in southern boreal Sweden. Acta Theriologica 45: 409-420.

The seasonal diet of pine marten Martes martes (Linnaeus, 1758) in southern boreal Sweden was studied by analyses of scats and digestive tract contents collected over a 6 -year period. The diet was diverse; whereas microtines was the single most important food category, also shrews, hares, birds, insects, and berries were frequently consumed. The diet of pine marten varied seasonally but the consumption of small mammals (microtines and shrews) and hares was relatively stable over the year, and may be regarded as a year-round staple for marten. The winter diet differed from most other Fennoscandian studies in that it contained more berries and insects, and less squirrels and cervids. This may be explained by the general lack of snow, and by the dense marten population, during the years of the study. Among birds passerines were most frequent; tetraonids were consumed mainly in winter. The food niche was broadest in winter and decreased over summer.

Grimsö Wildlife Research Station, Dept. of Conservation Biology, Swedish University of Agricultural Sciences, 73091 Riddarhyttan, Sweden, e-mail: j-o.helldin@nvb.slu.se

Key words: Martes martes, diet, seasonality, Sweden
\end{abstract}

\section{Introduction}

In most studies on pine marten Martes martes (Linnaeus, 1758) diet, small rodents are the principal prey, particularly in winter (Nasimovich 1948, Semenov-Tian-Shanskii 1959, Lockie 1961, Morozov 1976, Garzón et al. 1980, Braña and del Campo 1982, Wabakken 1985, Ansorge 1989, Eie 1992, Jędrzejewski et al. 1993, Clevenger 1993, Gurnell et al. 1994, Pulliainen and Ollinmäki 1996). Pine marten is, however, most often characterized as a food generalist, and also squirrels, shrews, cervid carcasses, birds, invertebrates, and berries may all be important prey (Nyholm 1970, Warner and O'Sullivan 1982, Marchesi and Mermod 1989, Storch et al. 1990, Pulliainen and Ollinmäki 1996, Sidorovich and Krasko 1997). The pine marten feeds opportunistically; its diet differs among seasons, years, and areas (Marchesi and Mermod 1989, Jędrzejewski et al. 1993, Clevenger 1994). Detailed knowledge about pine marten diet is fundamental for evaluation of the species' habitat requirements (Brainerd 1997), means of co-existence with other medium-sized carnivores (Storch et al. 1990, Clevenger 1993, 1994, Sidorovich and Krasko 1997), and role as predator on hole-nesting birds (Johnsson 1993) and small 
game (Angelstam et al. 1984, Marcström et al. 1988a, b). Accordingly, Clevenger (1994) stressed the need for further basic research on the diet of pine marten.

Most previous studies on pine marten diet in boreal Fennoscandia (here including Scandinavian Peninsula, Finland, and the adjacent Russian Lapland and Karelia) have been of short duration, or restricted to only part of the year (Semenov-Tian-Shanskii 1959, Höglund 1960, Nyholm 1970, Morozov 1976, Wabakken 1985, Storch et al. 1990, Pulliainen and Ollinmäki 1996, but see Nasimovich 1948). Here, multi-annual, year-round data on pine marten diet are presented, based on analyses of scats and contents of stomachs and intestines. The research was done as part of a larger study on pine marten habitat choice and population dynamics in the southern boreal forest of Sweden (see Lindström et al. 1995, Brainerd 1997). Part of the data used here was earlier analysed for among-year differences by Helldin (1999).

\section{Material and methods}

Scats were collected in the Grimsö Wildlife Research Area (GWRA), $140 \mathrm{~km}^{2}$ in south-central Sweden $\left(59^{\circ} 40^{\prime} \mathrm{N}, 15^{\circ} 30^{\prime} \mathrm{E}\right)$, and carcasses were obtained from the Bergslagen region, approximatively $10000 \mathrm{~km}^{2}$ surrounding GWRA, bounded in S and E by the southern border of the boreal zone (Sjörs 1963). The study area is described in detail by Helldin (1999).

Pine marten scats $(n=760)$ were collected from Dec 1988 through Apr 1995 (Table 1). A majority of scats $(n=535)$ were found along a system of forest trails (eight $1-2 \mathrm{~km}$ routes) distributed over the area. In the 6 summer months (mid-Apr to mid-Oct), trails were searched for scats monthly. In the 6 winter months (mid-Oct to mid-Apr), snow cover made collection at regular intervals impractical, and instead trails were searched 1 or 2 times when snow conditions were suitable, plus at the end of the season, after the snow had melted. Because of this, most winter scats could not be satisfactorily dated within the season. Scats were also collected at dens and resting sites of radiotagged martens $(n=62$; see Brainerd et al. 1995 for details on radiotracking), at other sites known to be used regularly by

Table 1. Number of pine marten scats and carcasses collected in south-central Sweden between Dec 1988 and Apr 1995, and used in diet analyses. Early summer - mid-Apr to mid-Jul, late summer mid-Jul to mid-Oct, early winter - mid-Oct to mid-Jan, late winter - mid-Jan to mid-Apr, and winter mid-Oct to mid-Apr.

\begin{tabular}{|c|c|c|c|c|c|c|c|}
\hline \multirow{3}{*}{ Year } & \multirow{2}{*}{\multicolumn{3}{|c|}{ Scats }} & \multicolumn{4}{|c|}{ Carcasses } \\
\hline & & & & \multicolumn{2}{|c|}{ Juveniles } & \multicolumn{2}{|c|}{ Adults } \\
\hline & Winter & $\begin{array}{c}\text { Early } \\
\text { summer }\end{array}$ & $\begin{array}{c}\text { Late } \\
\text { summer }\end{array}$ & $\begin{array}{c}\text { Early } \\
\text { winter }\end{array}$ & $\begin{array}{c}\text { Late } \\
\text { winter }\end{array}$ & $\begin{array}{c}\text { Early } \\
\text { winter }\end{array}$ & $\begin{array}{c}\text { Late } \\
\text { winter }\end{array}$ \\
\hline $1988-89$ & 22 & 26 & 4 & 1 & 3 & 4 & 2 \\
\hline 1989-90 & 40 & 53 & 18 & 27 & 14 & 31 & 27 \\
\hline 1990-91 & 61 & 52 & 33 & 37 & 32 & 31 & 36 \\
\hline $1991-92$ & 105 & 78 & 33 & 15 & 25 & 21 & 33 \\
\hline 1992-93 & 38 & 56 & 30 & 41 & 28 & 21 & 21 \\
\hline 1993-94 & 23 & 21 & 13 & & & & \\
\hline 1994-95 & 54 & & & & & & \\
\hline
\end{tabular}


marten for defecation $(n=146)$, while snow tracking $(n=13)$, and in live traps $(n=4)$. Scats were identified to species by size, shape, smell and location.

Pine marten carcasses with known date of capture $(n=450)$ were obtained from local trappers in the winters (15 Oct to 31 Mar) 1988-89 to 1992-93 (Table 1). A vast majority of these carcasses were taken in quick-kill traps, often baited with remains of game species (cervids, hares, and grouse) or domestic chicken (Helldin 1999). Seventy-five specimens showed clearly juvenile skeletal characters (temporal muscle undeveloped, tibia epiphysis open, baculum small; Strickland and Douglas 1987, Poole et al. 1994). The age of the other 375 was determined by counting cementum annuli on lower canines or second premolars (conducted by Matson's Laboratory, Milltown, Montana). Animals were gruoped in 2 age classes: juveniles (1st yr of life) and adults (the remaining).

Scats were dried at $110^{\circ} \mathrm{C}$ for $>5 \mathrm{hrs}$, weighed and examined dry. The contents of the distal $40 \mathrm{~cm}$ of the intestines (roughly the large intestines) were selected from the carcasses for complete diet analysis. This selection was made primarily because the contents of stomach and proximate intestines were considered to be more biased towards foraging close to the trap site and on the actual trap bait. Furthermore, restricting the analyses to the contents of the large intestines made these samples more comparable to scats; the mean dry weight of intestinal samples approximated the mean dry weight of scats (own unpubl. data), and should thus represent an equal foraging bout. Stomach contents of the carcasses were also examined, but for selected categories only (see below). Intestinal and stomach contents were examined wet.

Food remains were examined macroscopically and microscopically, and compared with literature (Day 1966, Brunner and Coman 1974, Debrot et al. 1982, Lundberg and de Jong 1995) and reference collections at Grimsö Wildlife Research Station and the Swedish Museum of Natural History (Stockholm). Food items were assigned to the most specific taxon possible, but were divided in 11 major categories (microtines, squirrels, shrews, hares, cervids, other mammals, birds, eggs, insects, berries, and miscellaneous) in the analyses. Undigestable plant material (such as leafs and twigs), non-organic material, undigested insects (that likely had entered the scat), and unidentifiable mucus (in intestines) were all excluded from the analyses. A food item was defined as an occurrence of a prey species in a scat, intestine, or stomach. Accordingly, a food item could be constituted by several similar small prey or just part of a large prey. For scats and intestinal contents, the percent of food items and of scat biomass attributed to each food category was calculated. The biomass was calculated by estimating the portion of an item in a scat by eye, and multiplying by the original dry weight of the scat (Reynolds and Aebischer 1991). I used percent of scat biomass to describe the general contribution of a food category to the diet, and percent of food items in comparisons among seasons (assuming a constant digestibility of a food type over the year). Stomach contents were analysed for shrews and birds, as remains of these two categories could rarely be identified to species in scats and intestines. Because galliform birds may be used as bait, I tested for bias towards these species in the stomach sample by comparing the ratio of passerines to galliforms with that in scats.

Four three-month seasons were defined: early summer (mid-Apr to mid-Jul), late summer (mid-Jul to mid-Oct), early winter (mid-Oct to mid-Jan), and late winter (mid-Jan to mid-Apr). Summer (early and late combined) corresponds roughly to the growing season (Vedin 1995). As scats could not be satisfactorily dated within the winter, early and late winter were separated only for the intestine sample. Contents of intestines differed from those of scats (Helldin 1999), which excluded pooling of these samples. Intestinal contents of juveniles and adults differed (Helldin 1999), and were thus treated separately. Samples from different years were pooled.

Diet among seasons (and vole consumption between ages, and bird consumption between scat, intestine, and stomach samples) was comared by contingency table analyses of actual counts of individual prey items. Because some prey types were scarce in intestines categories were pooled (squirrels/hares/other mammals, birds/eggs, and insects/miscellaneous) in the analysis of intestinal contents. Food niche breadth $(B)$ was calculated from the proportions of the 11 food categories in scats, as suggested by Hurlbert (1978):

$$
B=1 / \Sigma\left(p_{i}^{2} / q_{i}\right)
$$

where $p_{i}$ is the proportion of food items made up by category $i$, and $q_{i}$ the proportion of available food made up by category $i$. The food categories were arbitrarily assumed to be equally available, so that 
$q_{i}=1 / 11$. The variance of the food niche breadth $\left(V_{B}\right)$ was calculated by the "delta" method (Smith 1982):

$$
V_{B}=4 B^{4}\left(\sum\left(p_{i}^{3} / q_{i}^{2}\right)-1 / B^{2}\right) / n
$$

where $n$ is the total number of prey items in the sample. To compare niche breadth between periods of equal length, winter and summer were first compared, and then early and late summer separately.

\section{Results}

The pine marten utilized a wide array of food types; microtines, shrews, hares, birds, insects, and berries were all important food categories, constituting 9-30\% of scat biomass over the year (Table 2). The diet did not differ between early and late winter (intestine data; juveniles: $\chi^{2}=7.32, \mathrm{df}=6, p=0.30$; adults: $\chi^{2}=8.04, \mathrm{df}=$ $6, p=0.24$ ), but did so among other seasons (scat data; $\chi^{2}=268.67, \mathrm{df}=20, p<$ 0.0001 ). In winter the food niche was broader than in summer (mean $\pm \mathrm{SD}=0.663$ \pm 0.032 , compared to $0.478 \pm 0.022 ; t$-test: $t=4.76, \mathrm{df}=1427, p<0.0001$ ), and the diet was characterized by consumption of mammals (totalling $69 \%$ of scat biomass), most notably microtines, but also birds and berries were important food. In early summer, consumption of birds and insects increased in importance, but small mammals were still common prey. In late summer, the diet was dominated by microtines, insects, and berries, while other categories were particularly scarce. This resulted in a decreasing food niche breadth over summer (early summer: 0.475 \pm 0.028 ; late summer: $0.368 \pm 0.015$; $t$-test: $t=3.36, \mathrm{df}=842, p=0.001$ ).

Microtines was the single most important food category, and made up $\geq 20 \%$ of scat biomass in all seasons (Table 2). The relative consumption of microtines was higher in winter than in both early $\left(\chi^{2}=40.75, \mathrm{df}=1, p<0.0001\right)$ and late summer $\left(\chi^{2}=16.17, \mathrm{df}=1, p<0.0001\right)$, but did not differ between the 2 summer seasons $\left(\chi^{2}=0.30, \mathrm{df}=1, p=0.58\right)$. All 4 microtine species occurring in the area were consumed by marten, but bank voles Clethrionomys glareolus and field voles Microtus agrestis dominated (Table 2). These two species occurred in similar amounts in winter and early summer, but in late summer bank voles dominated over field voles. There was a tendency to a discrepancy between ages in this relation; juveniles consumed near-significantly more field voles relative to other microtines than did adults $\left(\chi^{2}=3.77, \mathrm{df}=1, p=0.052\right.$; Table 2).

Shrews constituted $12 \%$ of the total scat biomass (Table 2), and they were eaten all year; their proportion in the diet did not differ significantly among seasons $\left(\chi^{2}=3.40, \mathrm{df}=2, p=0.18\right)$. Shrew teeth were rarely found among food remains, so no shrew species could be identified in scats. In intestinal contents 1 pygmy shrew Sorex minutus was found, and in stomachs 1 pygmy shrew and 4 common shrews Sorex araneus. Nine percent of the total scat biomass consisted of hare remains (Table 2), and their proportion in the diet did not differ significantly among seasons $\left(\chi^{2}=3.54, \mathrm{df}=2, p=0.17\right)$.

Bird remains peaked at $23 \%$ of scat biomass in early summer (Table 2), but were not more frequent in early summer compared to winter $\left(\chi^{2}=2.59, \mathrm{df}=1, p=0.11\right)$. 
Table 2. Prey remains in pine marten scats and intestines collected in south-central Sweden between Dec 1988 and Apr 1995, presented as percent of food items (bold), percent by weight of scat biomass (bold in parenthesis), and actual number of items found (plain text). Eearly summer - mid-Apr to mid-Jul, late summer - mid-Jul to mid-Oct, early winter - mid-Oct to mid-Jan, late winter - mid-Jan to mid-Apr, and winter - early and late winter combined.

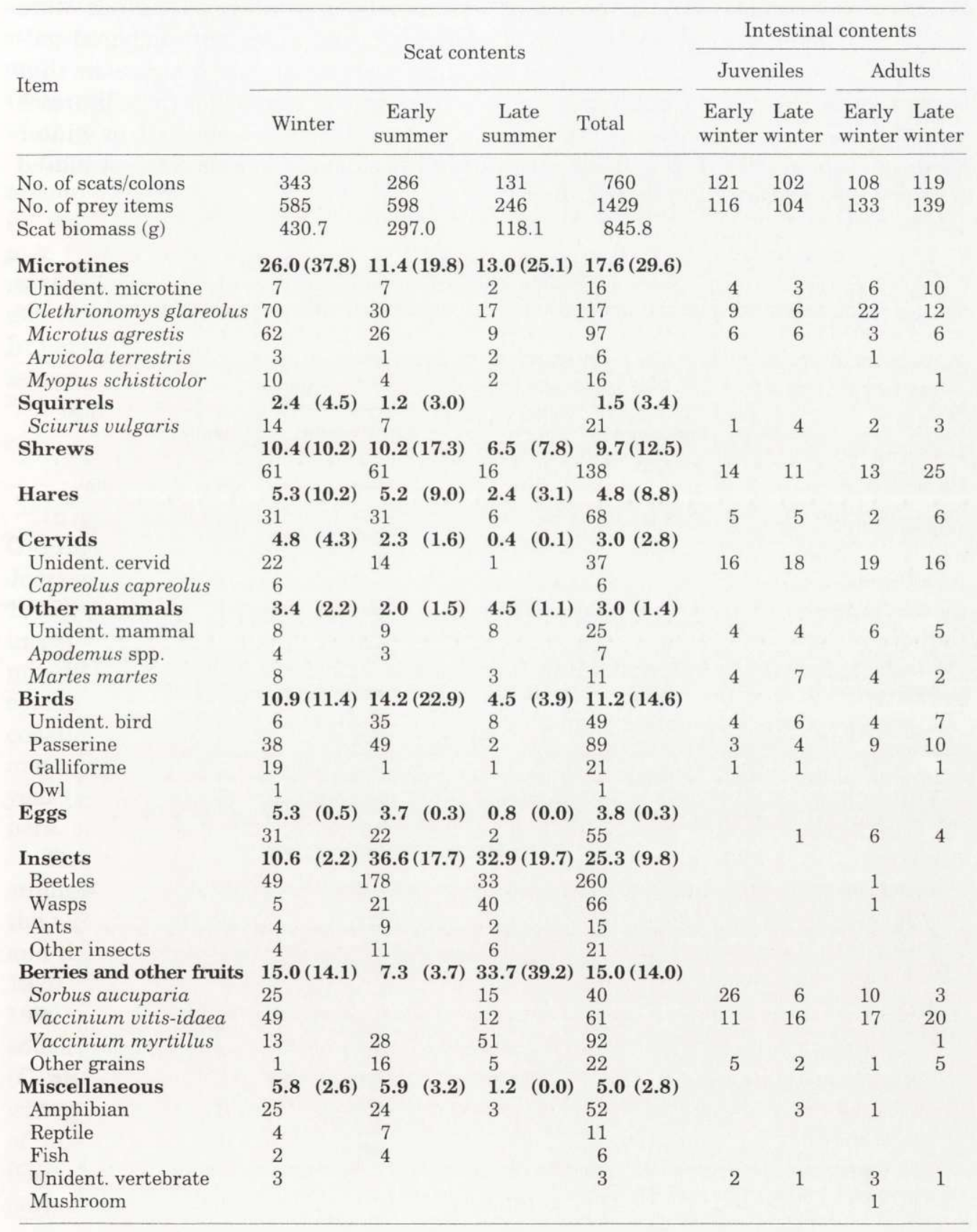


In late summer birds were less frequent compared to both winter $\left(\chi^{2}=8.06, \mathrm{df}=1\right.$, $p=0.004)$ and early summer $\left(\chi^{2}=15.46, \mathrm{df}=1, p<0.0001\right)$. Among birds identified to order or species passerines were most frequent, followed by galliformes, mainly forest grouse (Tables 2 and 3). Other bird species were sparsely represented. Whereas galliformes were eaten nearly exclusively in winter, passerines were frequently taken also in early summer. Although passerines outnumbered galliformes in winter scats, they formed a similar fraction of scat biomass in that season (passerines: $5.6 \%$, galliformes: $5.3 \%$ ). The ratio of passerines to galliformes in stomachs (ages and seasons combined) were not different from that in winter scats $\left(\chi^{2}=0.05, \mathrm{df}=1, p=0.83\right)$, suggesting the stomach sample was not biased towards bird species used as trap bait.

Table 3. Bird remains in pine marten stomachs collected in south-central Sweden between Dec 1988 and Apr 1995, presented as actual number of items found. Eearly winter - mid-Oct to mid-Jan, late winter - mid-Jan to mid-Apr.

\begin{tabular}{|c|c|c|c|c|c|}
\hline \multirow{2}{*}{ Item } & \multicolumn{2}{|c|}{ Juveniles } & \multicolumn{2}{|c|}{ Adults } & \multirow{2}{*}{ Total } \\
\hline & Early winter & Late winter & Early winter & Late winter & \\
\hline No. of stomachs & 121 & 102 & 108 & 119 & 450 \\
\hline Unident. bird & 4 & & 3 & 7 & 14 \\
\hline Anas sp. & & 1 & & & 1 \\
\hline Bucaphala clangula & & & & 1 & 1 \\
\hline Scolopax rusticola & & & & 1 & 1 \\
\hline Columba sp. & 1 & & & & 1 \\
\hline Picus viridis & 1 & & & & 1 \\
\hline \multicolumn{6}{|l|}{ Galliformes } \\
\hline Unident. galliforme & 2 & 4 & 2 & & 8 \\
\hline Tetrao tetrix & 5 & & 2 & 1 & 8 \\
\hline Tetrao urogallus & 1 & & 1 & 1 & 3 \\
\hline Bonasa bonasia & 1 & & 1 & 1 & 3 \\
\hline Domestic chicken & 2 & 1 & & & 3 \\
\hline \multicolumn{6}{|l|}{ Passerines } \\
\hline Unident. passerine & 3 & 5 & 2 & 10 & 20 \\
\hline Garrulus glandarius & 2 & 1 & & 3 & 6 \\
\hline Corvus corax & 1 & & & & 1 \\
\hline Turdus sp. & & & 2 & & 2 \\
\hline Turdus iliacus & 1 & & & & 1 \\
\hline Regulus regulus & & 1 & 5 & 4 & 10 \\
\hline Certhia familiaris & 1 & 1 & & 1 & 3 \\
\hline Troglodytes troglodytes & & & 1 & & 1 \\
\hline Parus major & & 1 & 3 & 1 & 5 \\
\hline Parus caeruleus & & 1 & 2 & 2 & 5 \\
\hline Parus ater & & 1 & 2 & & 3 \\
\hline Emberiza citrinella & 1 & 1 & & & 2 \\
\hline
\end{tabular}


In summer, insects constituted $18-20 \%$ of scat biomass, and $33-37 \%$ of food items (Table 2). The frequency of insects in scats did not differ between early and late summer $\left(\chi^{2}=0.88, \mathrm{df}=1, p=0.35\right)$, but were lower in winter than in the 2 summer seasons $\left(\chi^{2}=59.04\right.$ and $\left.109.15, \mathrm{df}=1, p<0.0001\right)$. In winter and early summer, insects were dominated by beetles, particularly dung-beetles Geotrupes stercorosus and carabids Carabus spp. In late summer, wasps were more frequent, and alone constituted $15 \%$ of the total scat biomass. In scats containing wasp remains, queens and males dominated over workers, pupae were found, and most often also wasp nest material.

Out of the total scat biomass, $14 \%$ were berries (Table 2), but the amount varied among seasons. The frequency of berries was higher in late summer than in winter $\left(\chi^{2}=35.91, \mathrm{df}=1, p<0.0001\right)$, and still lower in early summer $\left(\chi^{2}=16.85, \mathrm{df}=1\right.$, $p<0.0001$ ). Blueberries Vaccinium myrtillus, lingonberries V. vitis-idaea, and rowanberries Sorbus aucuparia were all frequently consumed in both late summer and winter. However, blueberries dominated in late summer, but not so in winter. In early summer, most berries were blueberries, probably consumed late in that season.

\section{Discussion}

In accordance with previous studies (Nasimovich 1948, Lockie 1961, Warner and O'Sullivan 1982, Marchesi and Mermod 1989, Storch et al. 1990, Clevenger 1993, Jędrzejewski et al. 1993, Ruiz-Olmo and López-Martín 1996, Sidorovich and Krasko 1997), the diet of pine marten varied seasonally. Among the major food categories, insects and berries were the most variable. Consumption of shrews and hares did not differ among seasons, and though the frequency of microtines did, it was constantly on a relatively high level. These three latter food categories combined constituted $51 \%$ of total scat biomass, and may be regarded as a year-round staple for marten. This despite the $5-10$-fold differences in small mammal abundance over the year (Hörnfeldt 1991), and the 2-4-fold differences in hare abundance ( $\AA$. Pehrson, pers. comm.).

The summer diet was generally similar to that reported in other Fennoscandian studies (Nasimovich 1948, Semenov-Tian-Shanskii 1959, Storch et al. 1990), but the winter diet contained more berries and insects, and less squirrels and cervids, and the birds consumed were not dominated by tetraonids (Höglund 1960, Nyholm 1970, Morozov 1976, Wabakken 1985, Storch et al. 1990, Pulliainen and Ollinmäki 1996). These characteristics make the diet more similar to that reported from southern Europe, eg Switzerland (Marchesi and Mermod 1989), and Spain (Cantabrian Mountains and Minorca; Clevenger 1993). During the present study, winters were poor in snow (Helldin 1999), which probably increased the availability of insects and some berries, and decreased the abundance of cervid carcasses (Cederlund and Lindström 1983, G. Cederlund, pers. comm.). In addition, it was a period of high marten density (Helldin 1994), which may have forced animals to 
forage on less profitable prey, and of low squirrel density (Delin 1996), which may explain the infrequent squirrel consumption. In resemblance with these findings, Nasimovich (1948) reported frequent consumption of berries (also mainly from Vaccinium-species and rowan) in winter, as well as rare consumption of squirrels and cervids, in Russian Lapland (Kola peninsula), but this was in a period with particularly deep snow.

The pine marten diet differed also among winters, mainly due to 3-4-year fluctuations in prey abundance (Helldin 1999), and the unbalanced sample among years, particularly among winters, may thus have introduced some error in the estimation of the seasonal diet. For example, the winter with most scats collected (1991/92) was also one with frequent consumption of lingonberries (38 of the 49 winter scats containing lingonberries were collected that year; Helldin 1999). Otherwise, no systematic bias with regard to year could be found, however. Berries accounted for an average of $13.3 \%$ of food items over the seven winters in the study (calculation from data in Helldin 1999), which is not very different from the $15.0 \%$ calculated from the pooled winter sample (Table 2). In similar comparisons for the other 10 food categories the differences were consistently smaller. Furthermore, the sampling period exceded the normal period of prey fluctuations. Because of this, I am confident that pooling of samples from different years did not affect the general results.

The relative importance of Clethrionomys over Microtus vole species in the pine marten diet has been a matter of discussion, as it may indicate marten foraging habitat choice and food competition with red fox Vulpes vulpes (Lockie 1961, Marchesi and Mermod 1989, Brainerd 1990, Storch et al. 1990, Jędrzejewski et al. 1993, Pulliainen and Ollinmäki 1996). Microtus voles are generally considered more profitable than Clethrionomys, due to their larger size and clumped distribution (Henttonen 1987). In a majority of studies in boreal Europe where vole species in marten diet were identified, Clethrionomys outnumbered Microtus (Nasimovich 1948, Wabakken 1985, Storch et al. 1990, Pulliainen and Ollinmäki 1996). However, in a few studies the situation was the opposite (Parovshchkov 1961, Morozov 1976), and in one (Höglund 1960) the numbers of the two genera were nearly equal. In the present study, bank voles and field voles occurred in comparable amounts in scats from winter and early summer, but bank voles dominated in late summer scats. Microtus occurs mainly in open, grassy habitats (Hansson 1978), which are generally avoided by martens (Brainerd et al. 1994), but Microtus may be taken by marten at forest edges (Jędrzejewski et al. 1993). The frequent consumption of Microtus in this study may suggest that martens benefit from a certain availability of open habitat, as proposed by several authors (Larin 1955, Krasovskii 1970, Grakov 1972, Brainerd 1990). It can, however, also be an effect of subordinate animals foraging in marginal habitats, as juveniles may have consumed relatively more field voles than had adults.

Jędrzejewski et al. (1993) reviewed occurrences of birds in marten diets, and concluded that marten selectively prey on woodpeckers, thrushes, tits, flycatchers, 
wrens, and in boreal forest also forest grouse. Though the present data supports their notion in general, I also recorded frequent consumption of goldcrest (Regulus regulus) and jay (Garrulus glandarius), but no flycatcher. The latter is not surprising, since flycatchers are migratory, and I rarely could identify birds occurring in the summer diet. The consumption of thrushes (Turdus spp.) and eggs in early winter is however interesting, as it implies long-term caching of food. In early winter no bird species breeds, so no eggs are available at that time. The thrushes were all consumed around new-year, when these migratory birds have normally left the region. Pine martens are known to cache eggs for $>6$ months (Höglund 1960, de Jounge 1981, Pulliainen 1981), and Pulliainen and Ollinmäki (1996) also found marten consumption of migratory birds in winter. Helldin (1999) speculated that cached eggs, although rare in diet analyses, may be an important winter food for adult martens, as such eggs can be easily obtained whenever most needed. The data presented here suggests that also juvenile martens may benefit from food caches in winter.

In accordance with this study, a large contribution seasonally of wasps and large beetles to marten diet was recorded by Warner and O'Sullivan (1982), and Marchesi and Mermod (1989). Insects formed a higher proportion of food items than of scat biomass. This indicates that martens eat only a few insects at a time, which probably reflects the foraging pattern on this prey category. The dominating beetles, dung-beetles and carabids, are common, large, solitary, forest floor-dwelling species, that could easily be devoured by a marten passing by. The foraging on wasps in late summer may be different, however, as wasp remains from this season often filled entire scats.

In conclusion, the results generally are in accordance with the notion of pine marten as a food generalist and opportunist. Consumption of some mammalian prey remained, however, stable over the year.

Acknowledgements: L. Hansson, H. Andrén, and A. Rodríguez commented on earlier drafts of this paper. L. Stjernlööw assisted in scat analyses, and the taxidermists at the Swedish Museum of Natural History in the identification of bird remains. Marten trappers in the region of Bergslagen provided carcasses. I received financial support from the Swedish Environmental Protection Agency and the private foundations "Oskar och Lili Lamms Minne" and "Olle och Signhild Engkvists Stiftelser" Thank's to you all.

\section{References}

Angelstam P., Lindström E. and Widén P. 1984. Role of predation in short-term population fluctuations of some birds and mammals in Fennoscandia. Oecologia 62: 199-208.

Ansorge H. 1989. Feeding ecological aspects of the pine marten, polecat, and stoat (Martes martes, Mustela putrius, Mustela erminea). [In: Populationsökologie marderartiger Säugetiere. M. Stubbe, ed]. Wissenschaftlige Beiträge University of Halle: 494-504. [In German with English summary]

Brainerd S. M. 1990. The pine marten and forest fragmentation: a review and general hypothesis. [In: Transactions of the 19th IUGB Congress. S. Myrberget, ed]. Trondheim: 421-434.

Brainerd S. M. 1997. Habitat selection and range use by the Eurasian pine marten (Martes martes) in relation to commercial forestry practices in southern boreal Scandinavia. $\mathrm{Ph} \mathrm{D}$ thesis, Agricultural University of Norway, Ås: 1-34. 
Brainerd S. M., Helldin J.-O., Lindström E. and Rolstad J. 1994. Eurasian pine martens and old industrial forest in southern boreal Scandinavia. [In: Martens, sables, and fishers: biology and conservation. S. W. Buskirk, A. S. Harestad, M. G. Raphael and R. A. Powell, eds]. Cornell University Press, Ithaca, New York: 343-354.

Brainerd S. M., Helldin J.-O., Lindström E. R., Rolstad E., Rolstad J. and Storch I. 1995. Pine marten (Martes martes) selection of resting and denning sites in Scandinavian managed forest. Annales Zoologici Fennici 23: 151-157.

Braña F. and del Campo J. C. 1982. Sobre la alimentacion de la marta, Martes martes, en Asturias. Boletín de Ciencias de la Naturaleza I. D. E. A. 29: 131-137.

Brunner H. and Coman B. J. 1974. The identification of mammalian hair. Inkata Press, Melbourne: $1-176$.

Cederlund G. and Lindström E. 1983. Effects of severe winters and fox predation on roe deer mortality. Acta Theriologica 28: 129-145.

Clevenger A. P. 1993. Pine marten (Martes martes) comparative feeding ecology in an island and mainland population of Spain. Zeitschrift für Säugetierkunde 58: 212-224.

Clevenger A. P. 1994. Feeding ecology of Eurasian pine martens and stone martens in Europe. [In: Martens, sables, and fishers: biology and conservation. S. W. Buskirk, A. S. Harestad, M. G. Raphael and R. A. Powell, eds]. Cornell University Press, Ithaca, New York: 326-340.

Day M. G. 1966. Identification of hair and feather remains in the gut and faeces of stoats and weasels. Journal of Zoology, London 148: 201-217.

Debrot S., Fivaz G., Mermod C. and Weber J.-M. 1982. Atlas des poils de mammiféres d'Europe. Institute of Zoology, University of Neuchâtel: 1-208.

Delin A. 1996. Habitat selection, movements and distribution of Eurasian red squirrel (Sciurus vulgaris) in boreal landscapes in relation to habitat fragmentation. M Sc thesis, Swedish University of Agricultural Sciences, Uppsala: 1-61.

Eie J. A. 1992. [Pine marten (Martes martes) prey choice in winter]. M Sc thesis, University of Oslo: 1-48. [In Norwegian]

Garzón J., de la Cuesta L., Ballarín I. and Palacios F. 1980. Datos preliminares sobre la alimentación de la marta (Martes martes) en España. Actas Reunión Iberoamercana de Conservación y Zoologia de Vertebrados 2: 378-384. [In Spanish with English summary]

Grakov N. N. 1972. Effect of concentrated clear fellings on the abundance of the pine marten (Martes martes). Byulleten Moskovskogo Obshchestva Ispytatelei Prirody, Otdelenie Biologii 77: 14-23. [In Russian with English summary]

Gurnell J., Venning T., MacCaskill B. and MacCaskill D. 1994. The food of pine martens (Martes martes) in West Scotland. Journal of Zoology, London 234: 680-683.

Hansson L. 1978. Small mammal abundance in relation to environmental variables in three Swedish forest phases. Studia Forestalia Suecica 147: 1-40.

Helldin J. O. 1994. [Marten hunting and trapping in mid-Sweden 1989-1993]. Viltforum 1994: 1, Swedish Hunter's Association, Uppsala: 1-8. [In Swedish]

Helldin J. O. 1999. Diet, body condition, and reproduction of Eurasian pine martens (Martes martes) during cycles in microtine density. Ecography 22: 324-336.

Henttonen H. 1987. The impact of spacing behavior in microtine rodents on the dynamics of least weasels Mustela nivalis - a hypothesis. Oikos 50: 366-370.

Höglund N. 1960. [Studies of the winter diet of pine marten (Martes m. martes) in County Jämtland]. Viltrevy (Swedish Wildlife) 1: 319-337. [In Swedish with German summary]

Hörnfeldt B. 1991. [Small mammal survey in PMK's reference areas]. Swedish Environmental Protection Agency, report 4122: 1-25. [In Swedish with English summary]

Hurlbert S. H. 1978. The measurement of niche overlap and some relatives. Ecology 59: 67-77.

Jędrzejewski W., Zalewski A. and Jędrzejewska B. 1993. Foraging by pine marten Martes martes in relation to food resources in Białowieża National Park, Poland. Acta Theriologica 38: 405-426.

Johnsson K. 1993. The black woodpecker Dryocopus martius as a keystone species in forest. $\mathrm{Ph} \mathrm{D}$ thesis, Swedish University of Agricultural Sciences, Uppsala: 1-144. 
de Jounge J. 1981. Predation of the pine marten (Martes martes) in relation to habitat selection and food abundance during winter in central Sweden. Swedish Environmental Protection Agency, report 1401: 1-31. [In Swedish with English summary]

Krasovskii L. I. 1970. A positive correlation between the abundance of pine martens and clear cuttings in European forests north of the USSR. Byulleten Moskovskogo Obshchestva Ispytatelei Prirody, Otdel Biologicheskii 75: 7-15. [In Russian with English summary]

Larin B. A. 1955. Influence of intensive forest-cutting on the productivity of trapping areas (preliminary report). Voprosy Biologii Pushnykh Zvereï, vol. XIV, Moskow, Russia. [English translation: 1959. Translations of Russian game reports 6: 148-158. Department of Northern Affairs and Natural Resources, National Parks Branch, Canadian Wildlife Service, Ottawa, Canada]

Lindström E. R., Brainerd S. M., Helldin J. O. and Overskaug K. 1995. Pine marten - red fox interactions: a case of intraguild predation? Annales Zoologici Fennici 32: 123-130.

Lockie J. D. 1961. The food of the pine marten Martes martes in west Ross-shire, Scotland. Proceedings from the Zoological Society, London 136: 187-195.

Lundberg P. and de Jong J. 1995. [Small mammals of Sweden]. Fältbiologerna, Stockholm: 1-94. [In Swedish]

Marchesi P. and Mermod C. 1989. Regime alimentaire de la martre (Martes martes) dans de Jura Suisse (Mammalia: Mustelidae). Revue suisse Zoologie 96: 127-146.

Marcström V., Keith L. B., Engren E. and Cary J. R. 1988a. Demographic responses of arctic hares (Lepus timidus) to experimental reductions of red foxes (Vulpes vulpes) and martens (Martes martes). Canadian Journal of Zoology 67: 658-668.

Marcström V., Kenward R. E. and Engren E. 1988b. The impact of predation on boreal tetraonids during vole cycles: an experimental study. Journal of Animal Ecology 57: 859-872.

Morozov V. F. 1976. Feeding habits of Martes martes (Carnivora, Mustelidae) in different regions of the north-west of the USSR. Zoologicheskii Zhurnal 55: 1886-1892. [In Russian with English summary]

Nasimovich A. A. 1948. [Ecology of pine marten]. Trudy Laplandskogo Gosudarstvennogo Zapovednika 3: 81-105. [In Russian]

Nyholm E. 1970. On the ecology of the pine marten (Martes martes) in eastern and northern Finland. Suomen Riista 22: 105-118. [In Finnish with English summary]

Parovshchkov V. Ya. 1961. On feeding habits of Martes martes borealis B. Kutznetz. near Archangelsk Zoologicheskiï Zhurnal 40: 1112-1115. [In Russian with English summary]

Poole K. G., Matson G. M., Strickland M. A., Magoun A. J., Graf R. P. and Dix L. M. 1994. Age and sex determination for American martens and fishers. [In: Martens, sables, and fishers: biology and conservation. S. W. Buskirk, A. S. Harestad, M. G. Raphael and R. A. Powell, eds]. Cornell University Press, Ithaca, New York: 204-223.

Pulliainen E. 1981. Food and feeding habits of the pine marten in Finnish Forest Lapland in winter. [In: Worldwide Furbearer Conference, Frostburg, Maryland. J. A. Chapman and D. Pursley, eds]: 580-598.

Pulliainen E. and Ollinmäki P. 1996. A long-term study of the winter food niche of the pine marten Martes martes in northern boreal Finland. Acta Theriologica 41: 337-352.

Reynolds J. C. and Aebischer N. J. 1991. Comparison and quantification of carnivore diet by faecal analysis: a critique, with recommendations, based on a study of the fox Vulpes vulpes. Mammal Review 21: 97-122.

Ruiz-Olmo J. and López-Martín J. M. 1996. Seasonal food of the pine marten (Martes martes) in a fir forest of Pyrenean mountains (north-eastern Spain). Proceedings from the 1st European Congress of Mammalogists, Museu Bocage, Lisboa, Portugal: 189-198.

Semenov-Tian-Shanskii O. I. 1959. On ecology of tetraonids. Trudy Laplandskogo Gosudarstvennogo Zapovednika 5: 1-318. [In Russian with English summary]

Sidorovich V. E. and Krasko D. A. 1997. Comparative analysis of feeding habits of pine marten and polecat. Habitat separation of the generalist mustelids in forests. [In: Mustelids in Belarus: 
evolutionary ecology, demography and interspecific relationships. V. E. Sidorovich, ed]. Zolotoy Uley Publisher, Minsk, Belarus: 122-126. [In Russian with English summary]

Sjörs H. 1963. Forest regions. Acta Phytogeographica Suecica 50: 48-63.

Smith E. P. 1982. Niche breadth, resource availability, and inference. Ecology 63: 1675-1681.

Storch I., Lindström E. and de Jounge J. 1990. Diet and habitat selection of the pine marten in relation to competition with the red fox. Acta Theriologica 35: 311-320.

Strickland M. A. and Douglas C. W. 1987. Marten. [In: Wild furbearer management and conservation in North America. M. Novak, J. A. Baker, M. E. Obbard and B. Malloch, eds]. Ontario Trappers Association, North Bay, Ontario: 530-546.

Vedin H. 1995. [Air temperature]. [In: Klimat, sjöar och vattendrag. B. Raab and H. Vedin, eds]. SNA Bokförlaget Bra Böcker, Höganäs: 44-57. [In Swedish]

Wabakken P. 1985. [Winter diet, habitat use, and hunting behaviour of pine marten (Martes martes) in south-eastern Norwegian coniferous forest]. M Sc thesis, University of Oslo: 1-87. [In Norwegian]

Warner P. and O'Sullivan P. 1982. The food of the pine marten Martes martes in Co. Clare. Transactions from the International Congress of Game Biology 14: 323-330.

Received 20 January 1999, accepted 6 September 1999. 